\title{
PENGARUH MODEL PEMBELAJARAN KOOPERATIF TIPE JIGSAW TERHADAP HASIL BELAJAR KIMIA MATERI POKOK TERMOKIMIA
}

\author{
Syamsul Hariadi ${ }^{1 *}$, Mukhtar Haris ${ }^{2}$, Eka Junaidi ${ }^{3}$ \\ 1,2,3 Program Studi Pendidikan Kimia FKIP Universitas Mataram \\ *Coressponding Author, Email: syamsulhariadi96@gmail.com
}

Received: 15 Juli

Accepted: 30 November

Publish: 30 November

doi: 10.29303/cep.v2i2.1288

\begin{abstract}
ABSTRAK
Penelitian ini bertujuan untuk mengetahui ada tidaknya pengaruh yang lebih baik dari model pembelajaran kooperatif tipe jigsaw terhadap hasil belajar kimia materi pokok termokimia pada peserta didik kelas XI MIPA SMAN 1 Gerung. Jenis penelitian yang digunakan berupa penelitian eksperimen semu dengan desain penelitian pretest-posttest control group design. Populasi dalam penelitian ini adalah seluruh peserta didik kelas XI MIPA SMAN 1 Gerung. Sampel dalam penelitian ini yaitu kelas XI MIPA 2 dan XI MIPA 4 yang ditentukan melalui teknik pengambilan sampel Purposive Sampling. Variabel bebas dalam penelitian ini adalah model pembelajaran kooperatif tipe jigsaw untuk kelas eksperimen (XI MIPA 4) dan model pembelajaran konvensional untuk kelas kontrol (XI MIPA 2). Variabel terikatnya adalah hasil belajar kimia peserta didik dalam ranah kognitif. Teknik pengumpulan data dilakukan dengan pemberian pretest dan posttest dalam bentuk tes pilihan ganda untuk mengukur hasil belajar peserta didik. Pengujian hipotesis dilakukan dengan menggunakan Gain uji-t dengan pengambilan keputusan didasarkan pada uji hipotesis dua pihak. Gain uji-t digunakan untuk menganalisis data hasil belajar kimia peserta didik, didapatkan thitung $(4,95)>$ ttabel $(1,67)$. Hasil tersebut menunjukkan bahwa model pembelajaran kooperatif tipe jigsaw berpengaruh lebih baik daripada model pembelajaran konvensional terhadap hasil belajar kimia materi pokok termokimia pada peserta didik kelas XI MIPA SMAN 1 Gerung.
\end{abstract}

Kata kunci : Model pembelajaran kooperatif tipe jigsaw, hasil belajar, termokimia

\section{THE INFLUENCE OF COOPERATIVE LEARNING MODEL OF JIGSAW TYPE FOR CHEMISTRY LEARNING RESULT OF CHEMISTRY ON THE SUBJECT MATTER OF THERMOCHEMISTRY}

\begin{abstract}
The purpose of this research is determine whether there is a better effect of the jigsaw type cooperative learning model on the learning result of chemistry on the subject matter of thermochemistry for XI MIPA students of SMAN 1 Gerung. The type of research was applied is quasi-experimental study with the design of the research technique pre-test and post-test control group design. The population in this research was the students' XI MIPA of SMAN 1 Gerung. The sample in the study was students of XI MIPA 2 and XI MIPA 4 which was determined through purposive sampling technique. The independent variables in this study were cooperative learning models for the experimental class (XI MIPA 4) and conventional learning models for the control class (XI MIPA 2). The dependent variable is chemistry learning result as well as students in cognitive aspect. Data collection techniques used by giving pre-test and post-test in the form of multiple choice tests to measure the result of students learning. Hypothesis test by using t-test gain with decision-making based on the hypothesis of the parties. Gain uji-t used to analyze students' chemistry learning outcomes data, obtained t-test score $(4.95)>$ t-table (1.67). These results concluded that the
\end{abstract}




\section{Chemistry Education Practice,2 (2), 2019 - 9}

Syamsul Hariadi, Mukhtar Haris, Eka Junaidi

cooperative learning model of students has a better effect than the conventional learning on the learning result of chemistry on the subject matter of thermochemistry to participants in XI MIPA students of SMAN 1 Gerung.

Keywords : jigsaw type cooperative learning model, learning outcomes, thermochemistry

\section{PENDAHULUAN}

Berdasarkan hasil observasi dan wawancara, ilmu kimia merupakan salah satu mata pelajaran yang abstrak dan dianggap sulit oleh peserta didik SMAN 1 Gerung yang mengakibatkan hasil belajar kimia peserta didik SMA tersebut umumnya rendah. Hal ini disebabkan oleh beberapa alasan, diantaranya yaitu pada saat proses belajar, tidak semua peserta didik yang aktif mengikuti pelajaran kimia serta kurangnya motivasi dari peserta didik itu sendiri. Pada proses pembelajaran, peserta didik tidak terlibat langsung, melainkan hanya mendengarkan ketika guru menggunakan metode ceramah dan hanya masuk dalam kelompok ketika guru menggunakan metode diskusi namun tidak fokus berdiskusi. Hal ini terlihat pada Tabel 1 .

Tabel 1. Nilai rata-rata ulangan akhir semester peserta didik kelas X MIPA SMAN 1 Gerung Tahun Pelajaran 2017/2018.

\begin{tabular}{cccc}
\hline Kelas & $\begin{array}{c}\text { Jumlah } \\
\text { Peserta } \\
\text { Didik }\end{array}$ & $\begin{array}{c}\text { Persentase } \\
\text { Ketuntasan }\end{array}$ & $\begin{array}{c}\text { Rata- } \\
\text { Rata }\end{array}$ \\
\hline X MIPA 1 & 32 & $34 \%$ & 62,62 \\
X MIPA 2 & 33 & $12 \%$ & 51,07 \\
X MIPA 3 & 34 & $0 \%$ & 42,20 \\
X MIPA 4 & 34 & $11 \%$ & 50,79 \\
X MIPA 5 & 33 & $0 \%$ & 42,77 \\
X MIPA 6 & 32 & $0 \%$ & 25,26 \\
Total & 198 & & \\
\hline
\end{tabular}

(Sumber: Arsip Sekolah 2018)

Rendahnya hasil belajar pada Tabel 1 kemungkinan disebabkan karena kurangnya motivasi dari peserta didik, pola pikirnya tentang pelajaran kimia yang abstrak, ribet, serta keterlibatannya dalam proses pembelajaran. Sekolah SMAN 1 Gerung sudah menerapkan Kurikulum 2013, namun penerapannya belum maksimal. Sehingga guru memilih menerapkan metode ceramah dan diskusi. Tipe diskusi kelompok yang sering diterapkan di sekolah ini adalah diskusi kelompok secara klasikal yaitu guru dan peserta didik membahas tugas atau soal latihan yang diberikan secara bersama-sama.

Oleh karena itu, peneliti bermaksud melakukan penelitian dengan menerapkan model pembelajaran yang menuntut keaktifan dan keterlibatan peserta didik dalam proses pembelajaran. Sehingga muncul belajar bermakna dengan terlibat langsung dalam proses pembelajaran. Peserta didik mampu melibatkan diri secara fisik, itelektual, dan mental dalam proses pembelajaran. Berdasarkan hasil penelitian yang telah dilakukan oleh Siahaan, dkk (2012) Siahaan (2010) dan Pebriana dkk. (2018) menggunakan model pembelajaran kooperatif dapat memberikan pengaruh yang lebih baik daripada model pembelajaran konvensional.

Salah satu model pembelajaran yang tepat untuk menangani masalah di atas adalah model pembelajaran kooperatif tipe jigsaw. Menurut Arends (dalam Alsa, 2010), pada pembelajaran dengan metode jigsaw, peserta didik belajar dalam kelompok yang anggotanya berkemampuan heterogen dan masing-masing peserta didik bertanggung jawab atas satu bagian dari materi.

Langkah-langkah model pembelajaran kooperatif tipe jigsaw menurut Priyanto (dalam Wena, 2014) sebagai berikut: (1) Pembentukan Kelompok Asal (Setiap kelompok asal terdiri dari 4-5 orang anggota dengan kemampuan yang heterogen), (2) Pembelajaran pada Kelompok Asal (Setiap anggota dari kelompok asal mempelajari submateri pelajaran yang akan menjadi keahliannya), (3) Pembentukan Kelompok Ahli (Ketua kelompok asal membagi tugas kepada masing-masing anggotanya untuk menjadi ahli dalam satu submateri pelajaran. Kemudian masing-masing ahli submateri yang sama dari kelompok yang berlainan bergabung membentuk kelompok baru yang disebut kelompok ahli), (4) Diskusi Kelompol Ahli (Anggota kelompok ahli mengerjakan tugas dan saling berdiskusi tentang masalah-masalah yang menjadi tanggung jawabnya), (5) Diskusi Kelompok Asal (Induk) (Anggota kelompok ahli kembali ke kelompok asal masing-masing. Kemudian setiap anggota kelompok asal 


\section{Chemistry Education Practice,2 (2), 2019 - 10}

Syamsul Hariadi, Mukhtar Haris, Eka Junaidi

menjelaskan dan menjawab pertanyaan mengenai submateri pelajaran yang menjadi keahliannya kepada anggota kelompok asal yang lain), (6) Diskusi Kelas (Dengan dipandu oleh guru diskusi kelas membicarakan konsep-konsep penting yang menjadi bahan perdebatan dalam diskusi kelompok ahli), (7) Pemberian Kuis (Kuis dikerjakan secara individu. Nilai yang diperoleh masing-masing anggota kelompok asal dijumlahkan untuk memperoleh jumlah nilai kelompok), dan (8) Pemberian Penghargaan Kelompok (Kepada kelompok yang memperoleh jumlah nilai tertinggi diberikan penghargaan berupa piagam dan bonus nilai).

Berdasarkan hasil penelitian Satuti (2011) dalam penelitiannya tentang pengaruh model pembelajaran kooperatif tipe jigsaw terhadap hasil belajar kimia peserta didik pada konsep laju reaksi mengatakan bahwa penerapan model pembelajaran kooperatif tipe jigsaw pada proses pembelajaran mempunyai pengaruh yang lebih baik terhadap hasil belajar kimia peserta didik, karena sistem belajar peserta didik dirubah menjadi belajar aktif dengan kelompok dan setiap kelompok dituntut untuk berpikir dan belajar dengan mengerahkan seluruh kemampuannya tanpa mengharapkan bantuan dari guru. Oleh karena itu, peneliti tertarik melakukan penelitian tentang model pembelajaran kooperatif tipe jigsaw karena di SMAN 1 Gerung belum pernah diterapkan pada materi termokimia.

Penelitian yang berjudul "Pengaruh Model Pembelajaran Kooperatif Tipe Jigsaw Terhadap Hasil Belajar Kimia Materi Pokok Termokimia Pada Peserta Didik Kelas XI MIPA SMAN 1 Gerung" dilakukan untuk mengetahui model pembelajaran kooperatif tipe jigsaw mampu memberikan pengaruh yang lebih baik terhadap hasil belajar kimia materi pokok termokimia pada peserta didik kelas XI MIPA SMAN 1 Gerung.

\section{METODOLOGI PENELITIAN}

Penelitian ini merupakan penelitian eksperimen. Penelitian eksperimen yaitu metode penelitian yang digunakan untuk mencari pengaruh perlakuan tertentu terhadap yang lain dalam kondisi yang terkendalikan (Sugiyono, 2013). Jenis eksperimen yang dimaksud adalah eksperimen semu (Quasi Experimental Design) yang terdiri atas kelas eksperimen dan kelas kontrol, dimana dalam desain penelitian jenis eksperimen semu ini, peneliti tidak selalu dapat melakukan pemilihan subjek secara random (individual random) (Setyosari, 2015). Peneliti tidak dapat memilih serta memilah subyek secara menyeluruh atau sebagian faktor yang dianggap dapat mengganggu hasil penelitian. Dengan kata lain, peneliti terpaksa harus menerima kelas atau kelompok-kelompok subyek yang sudah ditentukan oleh sekolah.

Desain penelitian yang digunakan dalam penelitian ini adalah pretest-posttest control group design, dimana pada desain ini observasi dilakukan sebanyak dua kali yaitu sebelum eksperimen dan sesudah eksperimen. Penelitian ini dilakukan di SMAN 1 Gerung dengan populasi seluruh peserta didik kelas XI MIPA Tahun Pelajaran 2017/2018. Teknik pengambilan sampel dalam penelitian ini adalah teknik purposive sampling, yaitu teknik sampling yang digunakan oleh peneliti jika peneliti mempunyai pertimbangan-pertimbangan tertentu di dalam pengambilan sampelnya (Arikunto, 2013). Sampel yang dipilih adalah kelas XI MIPA 2 (kelas kontrol) dan XI MIPA 4 (kelas eksperimen). Pengambilan sampel didasarkan pada pertimbangan guru yaitu kedua kelas tersebut paling kondusif dan cocok untuk dijadikan sampel. Pertimbangan lain yang digunakan dalam pemilihan sampel adalah pertimbangan dari peneliti yaitu kelas XI MIPA 2 dan XI MIPA 4 memiliki kemampuan yang hampir sama berdasarkan nilai rata-rata ulangan akhir semester kelas X MIPA (Tabel 1.1).

Pemberian perlakuan dimulai pada minggu pertama hingga minggu ke empat bulan Oktober 2018. Penelitian ini dilakukan sebanyak tujuh kali pertemuan yang terdiri dari satu kali pertemuan untuk pelaksanaan tes awal (pretest), lima kali pertemuan tatap muka belajar dan satu kali pertemuan untuk pelaksanaan tes akhir (posttest). Pada kelas kontrol digunakan model pembelajaran konvensional, sedangkan pada kelas eksperimen digunakan model pembelajaran kooperatif tipe jigsaw.

Analisis data menggunakan korelasi point biserial (Arikunto, 2013) untuk mengetahui validitas soal, KR-20 (Sugiyono, 2012) digunakan untuk mengetahui reliabilitas instrumen dan Gain uji-t (Arikunto, 2013) untuk menguji hipotesis penelitian. Pengujian normalitas digunakan rumus chi-kuadrat (Sugiyono, 2012) dan uji homogenitas varians digunakan uji-F (Sugiyono, 2012).

\section{HASIL DAN PEMBAHASAN}




\section{Chemistry Education Practice,2 (2), 2019 - 11}

Syamsul Hariadi, Mukhtar Haris, Eka Junaidi

Penelitian ini dilakukan untuk mengetahui hasil belajar kimia peserta didik pada materi pokok termokimia kelas XI MIPA SMAN 1 Gerung menggunakan model pembelajaran kooperatif tipe jigsaw. Penggunakan model pembelajaran kooperatif tipe jigsaw diyakini dapat meningkatkan hasil belajar kimia peserta didik.

Berdasarkan hasil analisis data, diperoleh nilai uji validitas ahli mengggunakan rumus Aiken'V berkisar 0,70-0,83 yang menunjukkan bahwa instrumen yang digunakan tergolong baik. Uji validitas tiap butir soal instrumen menggunakan rumus korelasi point biserial diperoleh 26 soal valid dari 28 soal yang diujikan pada taraf signifikan 5\% dengan rhitung yang berkisar antara 0,33 sampai 0,74 , sedangkan rtabel adalah 0,32 . Pengujian reliabilitas soal dihitung dengan menggunakan rumus K-R 20. Nilai reliabilitas soal yang diperoleh dari perhitungan 26 nomor soal yaitu 0,83 . Perolehan nilai tersebut tergolong dalam reliabel kriteria tinggi.

Hasil belajar peseerta didik dapat dilihat dari peningkatan nilai pretest hingga posttest pada ranah kognitif. Hasil belajar peserta didik dapat dilihat pada tabel 2 .

Tabel 2. Hasil pretest dan posttest kelas eksperimen dan kontrol.

\begin{tabular}{ccccc}
\hline & \multicolumn{2}{c}{ Pretest } & \multicolumn{2}{c}{ Posttest } \\
\hline & $\begin{array}{c}\text { Eksperime } \\
\mathrm{n}\end{array}$ & $\begin{array}{c}\text { Kontro } \\
1\end{array}$ & $\begin{array}{c}\text { Eksperime } \\
\mathrm{n}\end{array}$ & $\begin{array}{c}\text { Kontro } \\
1\end{array}$ \\
\hline $\begin{array}{c}\text { Ketuntasa } \\
\text { n klasika } \\
\text { Nilai }\end{array}$ & $0 \%$ & $0 \%$ & $56 \%$ & $18 \%$ \\
$\begin{array}{c}\text { Tertinggi } \\
\text { Nlai }\end{array}$ & 38 & 38 & 92 & 88 \\
$\begin{array}{c}\text { Terendah } \\
\text { Nilai rata- } \\
\text { rata }\end{array}$ & 8 & 8 & 58 & 54 \\
\hline
\end{tabular}

Tabel 2 menunjukkan bahwa nilai ratarata pretest kelas kontrol lebih besar daripada kelas eksperimen. Nilai tertinggi dan terendah di kelas eksperimen dan kelas kontrol memiliki nilai yang sama. Selain itu, nilai rata-rata posttest kelas eksperimen lebih tinggi daripada kelas kontrol. Nilai terendah, nilai tertinggi dan jumlah peserta didik yang tuntas di kelas eksperimen lebih tinggi daripada kelas kontrol.

Nilai rata-rata hasil pretest dan posttest kelas eksperimen dan kelas kontrol disajikan pada Gambar 5.1.

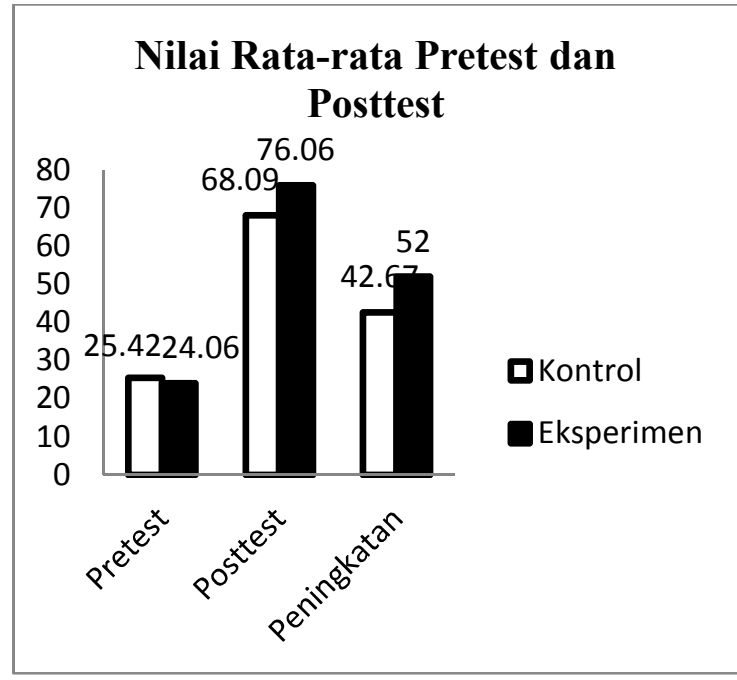

Gambar 1. Grafik nilai rata-rata pretest dan posttest

Gambar 1 menunjukkan bahwa nilai rata-rata pretest kelas kontrol lebih besar daripada kelas eksperimen, namun nilai rata-rata posttest kelas eksperimen lebih besar daripada kelas kontrol. Hasil pretest pada kedua kelas menunjukkan nilai rata-rata yang rendah dan masih di bawah KKM (75). Nilai yang rendah ini dikarenakan peserta didik belum memahami materi pokok termokimia meskipun sebelum pretest telah diberikan kesempatan belajar mandiri menggunakan buku paket pegangan peserta didik selama \pm 30 menit. Sedangkan pada hasil posttest, nilai rata-rata kedua kelas meningkat. Peningkatan nilai rata-rata ini disebabkan karena kedua kelas diberikan perlakuan model pembelajaran dan sudah mempelajari materi termokimia.

Nilai rata-rata hasil posttest yang cukup tinggi dengan model pembelajaran kooperatif tipe jigsaw dikarenakan model pembelajaran ini memacu peserta didik untuk lebih memahami dan menguasai materi pelajaran bersama dengan kelompoknya. Tahapan dari model pembelajaran kooperatif tipe jigsaw yang dapat meningkatkan hasil belajar peserta didik adalah terdapat pada tahap diskusi di kelompok ahli (jigsaw) dan tahap kembali ke kelompok asal. Ketika peserta didik berdiskusi di kelompok ahli, peserta didik yang satu dengan yang lain bertukar informasi dan pendapat mengenai materi atau permasalahan yang didapatkan. Artinya, semua peserta didik dalam anggota kelompok ahli tersebut ikut terlibat aktif dalam diskusi kelompok yang dapat meningkatkan pemahaman mereka mengenai materi yang didiskusikan. Selanjutnya, peserta didik kembali ke kelompok asalnya dengan tujuan untuk saling menjelaskan materi yang sudah didiskusikan di kelompok 


\section{Chemistry Education Practice,2 (2), 2019 - 12}

Syamsul Hariadi, Mukhtar Haris, Eka Junaidi

ahli kepada teman kelompok asalnya. Hal ini menuntut peserta didik untuk semakin meningkatkan pemahaman mereka karena mereka harus menjelaskan kembali ilmu yang sudah mereka dapatkan.

Belajar menggunakan model pembelajaran ini menyajikan pengalaman belajar kelompok yang menyenangkan. Karena dalam pembelajaran ini, setiap peserta didik melibatkan dirinya secara fisik, mental, dan intelektual dalam proses pembelajaran serta mampu mengerahkan seluruh kemampuannya dalam memahami materi yang didapatkan, terutama ketika sedang mengajarkan ilmu yang dipahami kepada teman dalam satu kelompoknya, sehingga hasil belajar mereka dapat meningkat.

Berdasarkan hasil observasi keaktifan peserta didik selama proses pembelajaran, peserta didik di kelas eksperimen lebih aktif daripada kelas kontrol. Hal ini terjadi karena model pembelajaran yang diterapkan di kelas eksperimen menuntut peserta didik untuk lebih aktif.

Hasil perhitungan menggunakan rumus gain uji-t, menunjukan bahwa thitung 4,95 sementara untuk nilai ttabel (pada taraf signifikan $5 \%$ dengan $\mathrm{dk}=65$ ) diperoleh ttabel sebesar 1,67. Nilai thitung $>$ ttabel, artinya $\mathrm{H} 0$ ditolak Ha diterima. Sehingga dapat disimpulkan bahwa model pembelajaran kooperatif tipe jigsaw memberikan pengaruh yang lebih baik daripada model pembelajaran konvensional terhadap hasil belajar kimia materi pokok termokimia pada peserta didik kelas XI MIPA SMAN 1 Gerung. Hal ini didukung dengan hasil penelitian yang dilakukan oleh Wijayanti (2012) yang mengatakan bahwa dengan menggunakan model pembelajaran kooperatif tipe jigsaw hasil belajar kimia peserta didik kelas X.I SMA Sang Timur Yogyakarta pada pokok bahasan Kimia Karbon dapat meningkat. Selain itu, Khusniyah, dkk (2014) mengatakan bahwa hasil belajar peserta didik yang diajarkan dengan model kooperatif Jigsaw IV lebih baik daripada yang diajarkan dengan model pembelajaran langsung.

Adapun permasalahan yang dialami peneliti di kelas eksperimen yaitu (1) tata ruang yang membutuhkan waktu sebelum mulai berdiskusi, (2) peserta didik masih merasa asing dengan model pembelajaran kooperatif tipe jigsaw meskipun peneliti sudah menjelaskan langkah-langkah model pembelajaran yang digunakan. Hal ini terlihat pada pertemuan ke dua, peserta didik masih kelihatan kaku dalam melakukan prosedur model pembelajaran kooperatif tipe jigsaw, sehingga suasana kelas terlihat gaduh, (3) pada saat diskusi berlangsung, konsidi kelas kurang kondusif yang membuat peserta didik lain merasa terganggu dalam proses pembelajaran, (4) ada beberapa peserta didik yang memiliki kemampuan lebih rendah dari anggota kelompoknya. Untuk mengatasi masalah tersebut, yang dilakukan peneliti pada penelitian ini yaitu: (1) guru membuat kesepakatan dengan peserta didik untuk menata ruang kelas sebelum proses pembelajaran dimulai, (2) guru atau peneliti memberikan informasi yang lebih detail kepada peserta didik ketika mereka mulai bingung dalam kegiatan pembelajaran. Pemberian informasi dilakukan juga pada pertemuan-pertemuan berikutnya, (3) peneliti membuat komitmen dengan peserta didik untuk fokus berdiskusi dengan anggota kelompoknya tampa membahas selain dari materi yang didiskusikan, (4) peserta didik yang kemampuannya lebih rendah dibantu oleh guru/peneliti.

Selain itu, permasalahan yang dialami peneliti di kelas eksperimen yaitu keterlambatan dimulainya pembelajaran. Hal ini dikarenakan banyaknya peserta didik yang masih di luar kelas pada jam keluar main telah selesai, sehingga waktu dimulainya pembelajaran tidak sesuai dengan waktu yang sudah direncanakan. Akibatnya, ada satu tahapan dari model pembelajaran kooperatif tipe jigsaw yang tidak dapat dilaksanakan yaitu kuis. Kuis dilakukan untuk mengetahui pemahaman peserta didik terhadap materi yang dipelajari dalam satu pertemuan. Oleh karena itu, pengujian pemahaman peserta didik terhadap materi disetiap pertemuan hanya dilakukan satu kali, yaitu pada saat posttest.

Pembelajaran di kelas kontrol cenderung kurang aktif karena masih terdapat beberapa peserta didik yang tidak ikut berpartisipasi pada saat diskusi berlangsung. Ada beberapa kelompok yang hanya mengandalkan satu atau dua orang anggota untuk menjawab tugas yang diberikan oleh guru. Hal ini disebabkan karena model pembelajaran yang digunakan tidak membuat semua peserta didik ikut berperan aktif di dalam proses pembelajaran. Selain itu, tingkat pemahaman peserta didik yang diajarkan menggunakan model pembelajaran konvensional lebih rendah dibandingkan peserta didik yang diajarkan menggunakan model pembelajaran kooperatif tipe jigsaw. 


\section{Chemistry Education Practice,2 (2), 2019 - 13}

Syamsul Hariadi, Mukhtar Haris, Eka Junaidi

\section{KESIMPULAN}

Berdasarkan hasil penelitian, maka dapat disimpulkan bahwa model pembelajaran kooperatif tipe jigsaw memberikan pengaruh yang lebih baik daripada model pembelajaran konvensional terhadap hasil belajar kimia materi pokok termokimia pada peserta didik kelas XI MIPA SMAN 1 Gerung.

\section{SARAN}

Bagi guru bidang studi kimia dapat mencoba menerapkan model pembelajaran kooperatif tipe jigsaw pada materi kimia yang lain. Bagi peneliti berikutnya dapat mencoba melaksanakan penelitian dengan menerapkan model pembelajaran kooperatif tipe jigsaw pada sekolah dan materi yang berbeda serta mendokumentasikan tiap-tiap tahap pembelajaran dan keadaan yang terjadi selama penelitian berlangsung sehingga dapat memperkuat hasil penelitian.

\section{DAFTAR PUSTAKA}

Alsa, A. (2010). Pengaruh Model Belajar Jigsaw Terhadap Keterampilan Hubungan Interpersonal dan Kerjasama Kelompok pada Mahasiswa Fakultas Psikologi. Jurnal Psikologi, 37 (2): 165-175.

Arikunto, S. (2013). Manajemen Penelitian. Jakarta: PT. Rineka Cipta.

Khusniyah, N., Retug, N., dan Redhana, I., W. (2014). Pengaruh Model Pembelajaran Kooperatif Jigsaw IV Terhadap Hasil Belajar Kimia Siswa SMA. Jurnal Wahana Matematika dan Sains, 8 (1). 1226.

Pebriana, L., Sukib, S., \& Junaidi, E. (2018). Pengaruh Model Pembelajaran Berbasis Masalah dengan Tipe Group Investigation (Gi) Terhadap Hasil Belajar Kimia Siswa. Chemistry Education Practice, 1(1), 6-12.
Satuti, M., D. (2011). Pengaruh Model Pembelajaran Kooperatif Tipe Jigsaw Terhadap Hasil Belajar Kimia Siswa Pada Konsep Laju Reaksi. UIN Syarif Hidayatullah: Skripsi.

Setyosari, P. (2015). Metode Penelitian Pendidikan dan Pengembangan. Edisi Keempat. Jakarta: Gramedia.

Siahaan, J. (2010). Dampak Penerapan Pendekatan Pembelajaran kooperatif Tipe Learning Together (TL) yang Dimodifikasi Dengan Berganti Peran Dan Peran Tetap Terhadap Hasil Belajar kimia Anorganik 1. Jurnal Pijar MIPA. 5 (2): 53-56.

Siahaan, J., Muti'ah, dan Dwirani, B., F., S. (2012). Upaya Meningkatkan Pemahaman Mahasiswa Akan Konsep-Konsep Kimia Dengan Penerapkan Paduan Metode Demonstrasi Dan Metode Kooperatif LT. Jurnal Pijar Mipa. 7 (1):1-42.

Sugiyono. (2012). Statistika Untuk Penelitian. Bandung: Alfabeta.

(2013). Metode Penelitian Pendidikan. Bandung: CV. Alfabeta.

Wijayanti, T., I. (2012). Model Pembelajaran Jigsaw Pada Pembelajaran Kimia Karbon Di Kelas X.I SMA Sang Timur Yogyakarta Tahun Pelajaran 2010/2011. Universitas Negeri Yogyakarta: Skripsi.

Priyanto. (2007). Keefektifan Pembelajaran Kooperatif Model Jigsaw pada Pembelajaran Kimia Siswa Kelas X Madrasah Aliyah Darut Taqwa. Malang: Tesis. 